\title{
Rejected Bullies or Popular Leaders? The Social Relations of Aggressive Subtypes of Rural African American Early Adolescents
}

\author{
Thomas W. Farmer, David B. Estell, Jennifer L. Bishop, Keri K. O’Neal, and Beverley D. Cairns \\ University of North Carolina at Chapel Hill
}

\begin{abstract}
Teacher assessments of interpersonal characteristics were used to identify subtypes of rural African American early adolescents (161 boys and 258 girls). Teacher ratings of interpersonal characteristics were used to identify popular and unpopular aggressive subtypes for both boys and girls. Unpopular aggressive youths did not have elevated levels of rejected sociometric status but were more likely to have lower levels of peer-perceived social prominence and social skills. Conversely, popular aggressive youths were more likely to be disliked by peers even though they were perceived by peers as socially prominent and socially skilled and were identified by teachers as highly involved in extracurricular activities. Both popular and unpopular aggressive youths tended to associate with others who had similar levels of peer-perceived popularity.
\end{abstract}

Over the past two decades, research on the social relations of youths has been marked by ambiguities on two distinct but related fronts. First, findings on the social relations of aggressive youths have been somewhat unclear and, at times, seemingly contradictory. Although aggressive youths are more likely to be rejected by their peers (Coie \& Dodge, 1998), most are members of peer groups, and some have prominent social positions (Bagwell, Coie, Terry, \& Lochman, 2000; Cairns, Cairns, Neckerman, Gest, \& Gariépy, 1988; Farmer \& Rodkin, 1996). Second, there is considerable confusion surrounding the relationship between popularity and being liked. Whereas indices of likability (i.e., sociometric status) have been viewed as a gold standard for identifying popular youths, many individuals who are perceived by classmates as being popular leaders are not well liked by their peers (Eder, 1985; LaFontana \& Cillessen, 1999; Lease, Kennedy, \& Axelrod, 2002; Parkhurst \& Hopmeyer, 1998). When these points are considered together, they may shed new light on the social dynamics of aggression in school. Our goal in this study was to help clarify these two issues by exploring the social relations of subtypes of aggressive youths.

Thomas W. Farmer, School of Education, University of North Carolina at Chapel Hill; David B. Estell, Jennifer L. Bishop, Keri K. O’Neal, and Beverley D. Cairns, Center for Developmental Science, University of North Carolina at Chapel Hill.

David B. Estell is now at the Department of Counseling and Educational Psychology, Indiana University.

This research was supported by Grants U81CCU416369 and R49CCR419824 from the Centers for Disease Control and Prevention to Thomas W. Farmer (Principal Investigator) and in part by National Institute of Mental Health Grant MH52429 to the Center for Developmental Science, University of North Carolina at Chapel Hill. The views expressed in this article are ours and do not represent those of the granting agencies.

Correspondence concerning this article should be addressed to Thomas W. Farmer, School of Education, Campus Box 8115, University of North Carolina, Chapel Hill, North Carolina 27599. E-mail: tfarmer@ email.unc.edu

\section{Social Relations of Aggressive Youths}

Findings on the social relations of aggressive youths have presented a paradox for researchers (Poulin, Dishion, \& Haas, 1999). On the one hand, sociometric status research clearly shows that aggressive and disruptive youths tend to have social skills deficits and are more likely to be rejected by their peers (Rubin, Bukowski, $\&$ Parker, 1998). On the other hand, beginning as early as preschool and extending through the school years, most aggressive youths tend to be members of peer groups and to associate with peers who are similar to them (Bagwell et al., 2000; Cairns et al., 1988; Estell, Cairns, Farmer, \& Cairns, 2002; Farmer \& Hollowell, 1994; Farver, 1996; Snyder, Horsch, \& Childs, 1997; Xie, Cairns, \& Cairns, 1999).

A confluence model has been proposed as a possible explanation for this paradox (Dishion, Patterson, \& Griesler, 1994). According to this model, aggressive youths begin school with inadequate social skills, are rejected by prosocial peers, and choose to affiliate with peers who reinforce their problematic behavior patterns. From this perspective, aggressive youths form deviant peer groups that are at the periphery of the social structure formed by their conventional peers. Although this model has considerable face validity, it has only been partially supported by research on the social positions and social networks of aggressive youth.

In contrast to the confluence model, several studies suggest that there are popular and unpopular subtypes of aggressive youths and that these subtypes may have distinct patterns of affiliation. In a study of the peer-assessed correlates of social network centrality in rural and suburban third- through sixth-grade classes, two distinct types of socially prominent (i.e., high social network centrality) boys were identified (Farmer \& Rodkin, 1996). One type received a high proportion of nominations for athleticism, popularity, and prosocial characteristics, whereas the other type was frequently nominated for athleticism, popularity, and antisocial characteristics. Similarly, Luthar and McMahon (1996) assessed the peer reputations of inner-city adolescents and found that both prosocial and aggressive/disruptive youths were perceived by peers as being popular.

Farmer and colleagues conducted a series of analyses of the social relations of popular and unpopular aggressive youths using 
cluster analytic methods with teacher ratings of interpersonal competence to identify behavioral subtypes in an ethnically diverse sample of urban, suburban, and rural youths in the fourth through sixth grades. Popular aggressive and unpopular aggressive configurations were identified for boys but not for girls (Farmer, Rodkin, Pearl, \& Van Acker, 1999). One male configuration (i.e., Tough) had high levels of teacher-assessed aggressive behavior, popularity, and athletic ability. Two other male configurations (i.e., Troubled and Bright Antisocial) were high in teacher-assessed aggression but low in popularity, athletic ability, and other socially favorable characteristics. Three aggressive configurations were identified for girls (i.e., Troubled, Bright Antisocial, and Very Unruly), and all included low levels of teacher-assessed popularity. A second analysis examined the social positions of boys in the different configurations (Rodkin, Farmer, Pearl, \& Van Acker, 2000). Tough boys were perceived by peers as being "cool" and were nuclear in the social network, much like boys who were viewed by teachers as popular and prosocial (i.e., Model boys). Troubled and Bright Antisocial boys received few nominations for "cool" and were more likely to have marginal social positions. A third analysis examined the distribution of aggressive youth in peer groups (Farmer et al., 2002). Using teacher and peer assessments of popularity and aggression, this analysis showed that Tough boys associated with popular and aggressive peers, whereas Troubled and Bright Antisocial boys were more likely to associate with nonaggressive and unpopular peers. Physically aggressive girls tended to be members of peer groups that were composed predominantly of other physically aggressive or unpopular girls.

Bagwell et al. (2000) examined peer cliques and sociometric status in fourth graders and found results similar to those described above. Rejected youths tended to be peripheral members of peer cliques that were relatively small and composed of other lowstatus peers. Nonrejected aggressive youths, but not rejected aggressive youths, tended to be core members of deviant peer groups. In fact, rejected boys were no more likely to associate with aggressive peers than were popular and average-status boys. These authors proposed a deviant peer clique hypothesis and suggested that nonrejected aggressive youths may be the leaders of deviant peer groups and that rejected aggressive youths may be at the periphery of these same groups.

\section{Likability and Popularity}

The concept of aggressive leaders reflects the second ambiguity in the research on childhood and adolescent peer relations. Although being well liked by peers (i.e., popular sociometric status) is commonly equated with popularity in the research literature, it may not be an adequate measure of an individual's actual position and influence in the social structure (Cairns, 1983). Ethnographic research on peer culture and social stratification supports this point. Youths tend to form social hierarchies during late childhood and early adolescence (Corsaro \& Eder, 1990). Studies have shown that in both elementary and middle school, girls who were perceived by their peers as being the most popular (i.e., cheerleaders, class leaders) were also among the most disliked (Adler, Kless, \& Adler, 1992; Eder, 1985). These studies suggested that this dislike occurred because popular girls tended to use a variety of socially aggressive strategies, including gossiping, starting rumors, and social exclusion, to help them maintain their high status. Similarly, boys in the most popular peer groups tended to have greater physical prowess, were more likely to be involved in extracurricular sports, tended to be socially dominant, and used aggressive and disruptive tactics to exert and maintain their social power (Adler \& Adler, 1995; Eder \& Parker, 1987). Further, narrative reports of peer conflict suggest that some popular youths may instigate episodes of collective bullying toward low-status peers to demonstrate and bolster their dominance over others (Adler et al., 1992; Evans \& Eder, 1993).

In support of these findings, several studies have distinguished between being well liked by peers (i.e., sociometric popularity) and being perceived by peers as popular (i.e., perceived popularity). Investigations in late elementary and middle-school classrooms suggest that there is only moderate correspondence between sociometric popularity and perceived popularity (LaFontana \& Cillessen, 1999; Parkhurst \& Hopmeyer, 1998). Many youths who are sociometrically popular are not viewed by peers as being popular, and many youths who are perceived as being popular are not well liked. Furthermore, youths' stereotypes of popularity tend to involve a mixture of both positive and negative elements (LaFontana \& Cillessen, 1998). Sociometric popularity appears to be linked with prosocial characteristics, whereas perceived popularity is associated with dominance, aggression, and being stuck-up (Parkhurst \& Hopmeyer, 1998). Also, perceived popularity, either alone or in combination with sociometric popularity, is related to peer nominations of admiration, leadership, and social power (Lease et al., 2002).

The concept of social aggression may help to explain why some youths who are perceived as being popular are also not well liked. Social aggression refers to the manipulation of group acceptance through alienation, ostracism, or character defamation (Cairns, Cairns, Neckerman, Ferguson, \& Gariépy, 1989) and is directed toward damaging another's self-esteem, status, or both (Galen \& Underwood, 1997). Socially aggressive strategies are often concealed and tend to be used by youths who are central in their classroom or school social networks (Xie, Swift, Cairns, \& Cairns, 2002). Perceived popular youths who are not well liked tend to be viewed by peers as socially aggressive (Lease et al., 2002), a finding consistent with ethnographic work on peer relations (e.g., Adler et al., 1992; Eder, 1985). Youths who are prominent leaders may use both prosocial and socially aggressive strategies to exercise their influence and therefore may not be well liked by their peers even though they are perceived as being popular (see Adler \& Adler, 1995; Hawley, Little, \& Pasupathi, 2002).

Although recent investigations suggest that there may be subtypes of aggressive boys who are prominent or nuclear leaders in their classroom social networks (Estell et al., 2002; Farmer \& Rodkin, 1996; Rodkin et al., 2000), the link between aggression and leadership is less clear with girls. As Underwood (2002) suggested, this may be due to the lack of studies that focus on social forms of aggression. Girls tend to be more adept at social aggression than boys (Xie, Cairns, \& Cairns, 2002), and because social aggression involves the effective manipulation of the social context (Xie, Cairns, \& Cairns, 2002), it follows that girls who are in leadership roles may be prone to use socially aggressive strategies. Consequently, there is a need to include social aggression variables in studies that examine subtypes of aggressive girls.

Considered collectively, findings on the social relations of aggressive youths and the characteristics of prominent leaders provide an intricate picture of the social dynamics of aggression in school. Although there is support for the confluence (i.e., Dishion 
et al., 1994) and deviant peer-group (i.e., Bagwell et al., 2000) models, there is also ample evidence to suggest that aggression may be linked to perceived popularity and leadership in the peer group. Therefore, although it is likely that some aggressive youths are socially unskilled and relegated to peripheral positions in the social structure, other aggressive youths may be leaders who associate with popular peers. Such youths may not be well liked because of their skill at using the social network to influence others.

\section{The Present Study}

The overarching aim of the present study was to clarify the linkages between aggression, likability (i.e., sociometric status), associations with popular peers, and perceived popularity and social prominence (i.e., teacher ratings, peer nominations). We expected that a more comprehensive view of the social dynamics of aggression could be achieved by examining differences across aggressive subtypes in relation to these variables. We were also interested in exploring whether the inclusion of social aggression measures in the analysis of behavioral configurations would result in the identification of a popular subtype of aggressive girls.

Four research aims guided this work. The first aim was to examine the sociometric status of youths in different configurations. We were interested in exploring whether teacher-perceived popular and unpopular subtypes differed from each other and from nonaggressive peers on sociometric status. The second aim was to explore whether teacher-perceived popular and unpopular subtypes of aggressive youths differed in how they were perceived by peers on a range of social and behavioral factors. The third aim was to examine the popularity level of youths' peer groups. We expected that teacher-perceived popular aggressive youths would be members of peer groups that contained several peer-perceived popular members (i.e., popular groups or mixed popular groups) and that teacher-perceived unpopular aggressive youths would have few, if any, peer-perceived popular associates (i.e., would be socially isolated or members of zero-popular or nonpopular groups). The fourth aim was to examine teacher ratings of social adaptation across aggressive subtypes. We expected the aggressive subtypes would be similar on general behavioral characteristics (e.g., attention problems, hyperactivity, bullies peers) but would differ on indices of social prominence (i.e., class leadership, extracurricular involvement). Because of possible gender differences, all analyses were conducted separately for boys and girls.

\section{Method}

A multimethod survey design was used that included teacher-, peer-, and self-report measures. Teacher assessments were used to construct behavioral configurations and to provide teacher information on indices of social adaptation. Peer reports and self-reports were used to identify classroom social networks and to assess participants' interpersonal characteristics.

\section{Participants}

This research was part of a longitudinal investigation examining the social adjustment of rural African American early adolescents who participated in the School Engagement Project (SEP; Cadwallader et al., 2002). The SEP involved providing classes in photography and American Jazz in the fifth and sixth grades with a focus on promoting youths' positive engagement in school. This study took place in two rural counties routinely identified in annual state reports as the poorest in a southern state. Over half of the school-age children in these counties live in households that are below the national poverty level. High crime rates and widespread substance abuse in the adolescent and young adult population are pressing concerns for local leadership. Although $40 \%$ of the population in these counties is European American, the student population in the public schools is over 99\% African American.

The sample consisted of 419 (161 boys and 258 girls) seventh- and eighth-grade adolescents from 18 classrooms in two schools. Girls made up $55 \%$ of the population in the two schools. One school was a self-contained middle school that served only seventh- and eighth-grade students. The other was a self-contained middle-school unit housed in a larger secondary school campus. It also served only seventh- and eighth-grade youths. Consistent with the public school attendance of these counties and reflecting the school population, over $99 \%$ of the participants (i.e., 417 of 419 ) in this study were African American. The overall participation rate was $80 \%$ (419/520) of the entire population in the two schools. This saturated sampling procedure allowed us to view each school as a single social context.

\section{Procedure}

Data were collected in the fall, 2 months after the beginning of the school year. Group administration procedures were used to conduct the survey with participants while their teachers completed the rating forms. Before the administration of the survey, participants were assured that their answers would be kept confidential, and they were asked to protect the confidentiality of their responses. Participants were also told they could stop participating at any time. The surveys were conducted in teams that included African American research assistants from the community where the study was being conducted. During the survey, one administrator read the instructions and questions aloud. Additional administrators provided mobile monitoring and assisted students as needed.

For all peer nomination measures, the focus of the probe was at the school level (i.e., participants were told that they could nominate any peer in their school). This focus was chosen because the samples in both schools were saturated (i.e., all the classes in the school participated in the study), there was considerable interaction among classes and grades, these were relatively small middle schools, and there was little transience in the school populations (i.e., participants were highly familiar with each other). Also, all peer nominations were made from free recall (i.e., no class rosters were provided) because social cognitive mapping procedures were developed specifically to tap youths' maps of their school's social structure from free recall.

\section{Measures}

Interpersonal Competence Scale-Teacher (ICS-T). The ICS-T is an 18-item questionnaire consisting of 7-point Likert scales that teachers completed for each participant in their classes. The ICS-T yields composite scores on five primary subscales: Aggressive (composed of "always argues," "gets in trouble," and "always fights"; Cronbach's $\alpha=.82$ ), Popular (composed of "popular with boys," "popular with girls," and "lots of friends"; $\alpha=.81$ ), Academic (composed of "good at math" and "good at spelling"; $\alpha=.71$ ), Affiliative (composed of "always smiles" and "always friendly"; $\alpha=.71$ ), and Olympian (composed of "good at sports," "good looking," and "wins a lot"; $\alpha=.67)$. Three-week test-retest reliability coefficients are moderately high (i.e., .80-.92), and median test-retest correlations across the factors are .81 for girls and .87 for boys. One-year coefficients are moderately strong (i.e., .40-.50; Cairns, Leung, Gest, \& Cairns, 1995). The ICS-T has convergent validity with direct observation, student records (i.e., grades, discipline reports), and peer nomination measures (Cairns \& Cairns, 1994; Cairns, Leung, Buchanan, \& Cairns, 1995; Leung, 1996; Rodkin et al., 2000), and it has predictive validity over an 8-year period for adult adjustment (Cairns \& Cairns, 1994; Mahoney, 2000). 
Teacher ratings of social adaptation. A second rating measure was used that focused on specific aspects of social adaptation. Using the same 7-point Likert format of the ICS-T, this measure included seven items: "attention problems," "class leadership," "hyperactive," "bullied by peers," "manipulates friendships," "bullies peers," and "participates in extracurricular activities." In addition, six items on 3-point scales were included that focused on reactive and proactive aggression: "uses physical force," "bullies to get their way," "gangs up on disliked peers" (collectively, proactive aggression), "angers easily when threatened," "overreacts with anger," and "blames other children" (collectively, reactive aggression).

Social cognitive maps (SCM). For this measure, participants were asked, "Are there some kids in your school who hang around together a lot? Who are they?" Following the procedures developed by Cairns and colleagues (e.g., Cairns, Perrin, \& Cairns, 1985), we instructed participants to list from free recall as many groups as they could think of in their school. SCM procedures have been used extensively in research on school social networks (e.g., Cairns et al., 1988; Farmer \& Cairns, 1991; Farmer \& Hollowell, 1994; Farmer et al., 2002; Farmer, Stuart, Lorch, \& Field, 1993; Kindermann, 1993; Leung, 1996; Rodkin et al., 2000; Xie et al., 1999). Peer groups identified by the SCM procedure have been validated by analyses of youths' classroom interactional patterns (Gest, Farmer, Cairns, $\&$ Xie, in press). Three-week test-retest reliability coefficients indicate high short-term stability of children's peer groups (i.e., 90\% of groups maintain a majority of their members over this period; Cairns, Leung, Buchanan, \& Cairns, 1995).

To identify distinct groups within the school social network, we analyzed the SCM data with the SCM 4.0 computer program (Leung, 1996), following the procedures outlined by Cairns, Gariépy, Kindermann, and Leung (1996). This program constructed three matrices. First, a recall matrix was generated by listing all the groups named by each respondent. Second, a co-occurrence matrix was created by listing the number of times that each pair of individuals was named together. This provided a cooccurrence profile of each individual in the school social structure. Third, on the basis of the assumption that youths who are members of the same group will have similar affiliative patterns, a correlational matrix was generated from the co-occurrence profiles. Students whose profiles were significantly correlated with at least $50 \%$ of the members of a group were considered to be in the group (Cairns, Leung, Buchanan, \& Cairns, 1995). For a more detailed description and illustration of these procedures, see Farmer et al. (1993).

Peer interpersonal assessments. Peer interpersonal assessments were used to determine classmates' perceptions of peers' social and behavioral characteristics. Students were asked to nominate, from free recall, three peers who best fit descriptors for 16 items. They were told that they could nominate themselves and that they could nominate the same person for more than one item. The items were as follows: "cooperative" ("Here is someone who is really good to have as part of your group, because this person is agreeable and cooperates-pitches in, shares, and gives everyone a turn."); "disruptive" ("This person has a way of upsetting everything when he or she gets into a group-doesn't share and tries to get everyone to do things their way."); "acts shy" ("This person acts very shy with other kids. It's hard to get to know this person."); "starts fights" ("This person starts fights. This person says mean things to other kids or pushes them, or hits them."); "seeks help" ("This person is always looking for help, asks for help even before trying very hard."); "leader" ("This person gets chosen by the others as the leader. Other people like to have this person in charge."); "athletic" ("This person is very good at many outdoor games and sports."); "gets in trouble" ("This person doesn't follow the rules, doesn't pay attention, and talks back to the teacher."); "good student" ("This person makes good grades, usually knows the right answer, and works hard in class."); "cool" ("This person is really cool. Just about everybody in school knows this person."); "sad" ("This person often seems sad."); "starts rumors" ("This person gossips and says things about others. This person is good at causing people to get mad at each other."); "popular" ("Some kids are very popular with their peers. That is, many classmates like to play with them or do things with them."); "picked on" ("This person is picked on by others."); "friendly" ("This person is usually friendly to others."); and "bully" ("This person is always hurting or picking on others."). Threeweek test-retest reliability with individual items ranged from .72 to .93 . These items are identical or similar to peer assessments used by other investigators (e.g., Cantrell \& Prinz, 1985; Coie, Dodge, \& Coppotelli, 1982; Masten, Morison, \& Pellegrini, 1985).

The total number of nominations participants received for each peer assessment item was divided by the total number of possible nominators (i.e., all participants in the school). Because the denominator was the total number of participants in each school, the resulting proportions were small. In order to make mean differences clearer, we linearly transformed these proportions by multiplying them by 1,000 .

A factor analysis of these 16 items yielded a four-factor solution consisting of Aggression (Cronbach's $\alpha=.88$; consists of "disruptive," "starts fights," "gets in trouble," "starts rumors," and "bully"), Prosocial Skills ( $\alpha=.79$; consists of "cooperative," "good student," and "friendly"), Social Prominence ( $\alpha=.85$; consists of "leader," "athletic," "cool," and "popular"), and Internalizing ( $\alpha=.56$; consists of "acts shy," "seeks help," "sad," and "picked on").

Sociometric status. Following the procedures outlined by Coie, Dodge, and Coppotelli (1982), we asked participants to "name the three classmates you like most" and "name the three classmates you like least." Sociometric status was calculated following the methodology described by Coie et al. (1982). Each participant's social preference score was defined by his or her standardized number of nominations received for being most liked minus his or her standardized number of nominations received for being least liked. Further, a social impact score was calculated by adding the standardized number of nominations received for being most liked to the standardized number of nominations received for being least liked. Students with a standardized social preference score greater than 1.0, a standardized most liked score greater than 0 , and a standardized least liked score less than 0 were classified as "sociometrically popular." Those with a standardized social preference score less than 1.0, a standardized most liked score less than 0 , and a standardized least liked score greater than 0 were classified as "sociometrically rejected." "Sociometrically neglected" participants had standardized social impact scores less than -1.0. "Sociometrically controversial" participants had standardized social impact scores greater than 1.0 and standardized most and least liked scores greater than 0. All other participants were classified as "sociometrically average."

\section{Data Reduction Procedures}

Behavioral configurations. Behavioral configurations were derived to determine subtypes of students from the teacher ratings. Configurations were identified using Ward's (1963) clustering algorithm and were based on the five main ICS-T factors (Aggressive, Popular, Academic, Affiliative, and Olympian) in boys, and these five factors plus three teacherassessed social adaptation indices of social aggression ("manipulates friendships," "class leader," and "bullies peers") were used for girls. These scores were standardized by sex, and configurations were determined separately for boys and girls. With this method, we measured the similarity between students' profiles by squared Euclidean differences to determine homogeneous subgroups of students. We decided on the number of configurations to retain by examining a scree plot of distance coefficients as a function of the number of configurations at each agglomerative step (cf. Aldenderfer \& Blashfield, 1984).

Peer-group types. Participants were classified according to their peernominated popularity in order to determine peer-group type as a function of the proportion of popular members in the group. The proportion of popular nominations was standardized within gender, and boys and girls who were in the top $30 \%$ of nominations were classified as popular.

Peer groups identified by the SCM analysis described above were classified according to the popularity level of their constituent members. Four group types were identified. Zero-popular groups had no popular members. Nonpopular groups had 1 or 2 popular members, but more than 
half the members were nonpopular. Popular groups had 1 or 2 nonpopular members, but more than half the members were popular. Mixed groups had at least 2 popular and 2 nonpopular members.

\section{Results}

\section{Behavioral Configurations}

Analyses of the dendrograms and explained error sums of squares indicated that four clusters were the optimum solution for both boys and girls. The inclusion of more clusters did not increase explanatory power more than a minimal amount for either gender. The clusters are shown in Tables 1 (boys) and 2 (girls).

The clusters that emerged in boys are as follows:

Model boys: above-average scores on Popular, Academic, Affiliative, and Olympian; below-average score on Aggressive.

Tough boys: above-average scores on Aggressive, Popular, and Affiliative; average scores on Academic and Olympian.

Average boys: below-average scores on Aggressive and Affiliative; average scores on Popular, Academic, and Olympian.

Troubled boys: above-average score on Aggressive; belowaverage scores on Popular, Academic, Affiliative, and Olympian.

The clusters that emerged in girls are as follows:

Model girls: above-average scores on Popular, Academic, Affiliative, Olympian, and "class leader"; below average scores on Aggressive, "manipulates friendships," and "bullies peers."

Popular girls: above-average scores on Popular, Academic, Affiliative, Olympian, "class leader," and "manipulates friendships"; average scores on Aggressive and "bullies."

Below Average girls: above-average score on Affiliative; below-average scores on Aggressive, Academic, "class leader," "manipulates friendships," and "bullies peers"; average scores on Popular and Olympian.

Troubled girls: above-average scores on Aggressive, "manipulates friendships," and "bullies peers"; below-average scores on Popular, Academic, Affiliative, Olympian, and "class leader."

Although there was some overlap in the clusters across gender, the labels are used only for descriptive purposes and are not intended to imply specific behavioral traits. Therefore, although the Model and Troubled labels are used to describe configurations for both boys and girls, they should not be viewed as being direct parallels. As indicated by the means and standard deviations in
Tables 1 and 2, there are differences between the boys and girls in configurations that have the same label. Nonetheless, these labels provide a helpful heuristic for understanding differences in the profiles relative to other configurations within the same gender.

\section{Behavioral Configurations and Sociometric Status}

This section explores the relationship between behavioral subtypes and sociometric status categories. As shown in Table 3, there was not an overall relationship between behavioral configuration subtype and sociometric status in boys, $\chi^{2}(12, N=130)=16.94$, $p=.15$. However, there were three significant cell-specific relationships. There were fewer rejected Model boys (Fisher's exact probability $<.05$ ), more rejected Tough boys (Fisher's exact probability $<.01$ ), and fewer neglected Tough boys (Fisher's exact probability $<.05$ ) than expected by chance.

There was a marginal overall relationship between behavioral subtype and sociometric status in girls, $\chi^{2}(12, N=231)=19.56$, $p=.08$ (see Table 4). This effect was driven by two cells. Popular girls were more likely to be controversial (Fisher's exact probability $<.01$ ) and less likely to be neglected (Fisher's exact probability $<.05)$ than expected by chance.

\section{Behavioral Configurations and Peer Nominations}

This section examines whether peers differentially perceived youths in the various behavioral subtypes. As shown in Table 5, the boys' configurations differed from each other on both peernominated Aggression, $F(3,136)=3.90, p<.01$, and peernominated Prosocial Skills, $F(3,136)=3.48, p<.05$, but not peer-nominated Social Prominence, $F(3,136)=1.03, p=.38$, or peer-nominated Internalizing, $F(3,136)=0.53, p=.66$.

Differences were probed by post hoc Tukey's tests. Tough boys had significantly more peer nominations for Aggression than Model and Average boys. Model boys had significantly more nominations for Prosocial Skills than did Troubled boys. Though the omnibus $F$ test was not significant, preplanned contrasts indicated that Model and Tough boys were significantly higher on the Social Prominence factor than were Troubled boys, $t(136)=2.72$, $p<.01$.

Table 1

Boys' Behavioral Configurations

\begin{tabular}{lrrrrr}
\hline & \multicolumn{5}{c}{ Variable } \\
\cline { 2 - 6 } \multicolumn{1}{c}{ Cluster } & Aggressive & Popular & Academic & Affiliative & Olympian \\
\hline Model $(n=43)$ & & & & & \\
$M$ & -0.70 & 0.74 & 0.47 & 0.69 & 0.58 \\
$S D$ & 0.55 & 0.66 & 1.12 & 0.56 & 0.94 \\
Tough $(n=18)$ & -0.93 & 1.20 & 0.25 & 0.84 & 0.19 \\
$M$ & 0.55 & 0.51 & 0.56 & 0.39 & 0.73 \\
$S D$ & -0.50 & -0.18 & -0.11 & -0.46 & -0.23 \\
Average $(n=33)$ & 0.89 & 0.56 & 1.00 & 0.78 & 0.89 \\
$M$ & & & & & -0.58 \\
$S D$ & 0.55 & -0.85 & -0.49 & -0.58 & 0.77 \\
Troubled $(n=46)$ & 0.83 & 0.53 & 0.78 & 0.87 & \\
$M$ & & & & & \\
$S D$ & & & & & \\
\hline
\end{tabular}


Table 2

Girls' Behavioral Configurations

\begin{tabular}{|c|c|c|c|c|c|c|c|c|}
\hline \multirow[b]{2}{*}{ Cluster } & \multicolumn{8}{|c|}{ Variable } \\
\hline & Aggressive & Popular & Academic & Affiliative & Olympian & Leader & Manipulates & Bullies \\
\hline \multicolumn{9}{|l|}{ Model $(n=46)$} \\
\hline$M$ & -0.86 & 0.56 & 1.08 & 0.79 & 0.57 & 1.15 & -0.95 & -0.73 \\
\hline$S D$ & 0.41 & 0.87 & 0.67 & 0.62 & 1.13 & 0.49 & 0.19 & 0.18 \\
\hline \multicolumn{9}{|l|}{ Popular $(n=48)$} \\
\hline$M$ & 0.17 & 0.73 & 0.62 & 0.38 & 0.39 & 0.40 & 0.63 & -0.09 \\
\hline$S D$ & 0.80 & 0.60 & 0.52 & 0.59 & 0.73 & 0.77 & 0.89 & 0.78 \\
\hline \multicolumn{9}{|c|}{ Below Average $(n=57)$} \\
\hline$M$ & -0.61 & 0.11 & -0.55 & 0.26 & -0.11 & -0.64 & -0.76 & -0.66 \\
\hline$S D$ & 0.59 & 0.95 & 0.88 & 0.95 & 0.99 & 0.76 & 0.47 & 0.26 \\
\hline \multicolumn{9}{|c|}{ Troubled $(n=73)$} \\
\hline$M$ & 0.92 & -0.71 & -0.64 & -0.82 & -0.53 & -0.49 & 0.78 & 1.03 \\
\hline$S D$ & 0.79 & 0.55 & 0.57 & 0.67 & 0.81 & 0.68 & 0.69 & 0.91 \\
\hline
\end{tabular}

The girls' configurations differed from each other on three peer-nomination factors (see Table 6). These included Aggression, $F(3,224)=4.51, p<.01$, Prosocial Skills, $F(3,224)=12.44$, $p<.01$, and Social Prominence, $F(3,224)=6.99, p<.01$. They did not differ on Internalizing, $F(3,224)=2.20, p=.09$.

These differences were probed by post hoc Tukey's tests, which indicated that Popular girls were nominated as being more aggressive than Model and Below Average girls, and Troubled girls were nominated as being more aggressive than Model girls. Model and Popular girls were nominated as higher in prosocial skills than Below Average and Troubled girls. Finally, Popular girls were nominated as having higher social prominence than either Below Average or Troubled girls.

\section{Peer Groups}

A total of 42 male groups were identified that ranged in size from 2 to 16 members. The mean group size for boys was 4.95. A total of 59 female groups were identified that ranged in size from
2 to 13 members. The mean group size for girls was 4.75 . These means and ranges are consistent with those from other studies of late elementary and middle-school peer groups (Bagwell et al., 2000; Cairns et al., 1988; Coie, Terry, Zakriski, \& Lochman, 1995; Farmer \& Hollowell, 1994; Pearl et al., 1998; Xie et al., 1999).

\section{Behavioral Configurations and Peer-Group Type}

This section examines whether youths' peer-group membership type was related to their behavioral subtype. We expected that Model, Tough, and Popular youth would be more likely to be members of groups that contained a high proportion of popular peers and that youths in the Troubled configurations would be less likely to be in such groups. We were particularly interested in whether there were differences in the affiliative profiles of the two types of aggressive boys (i.e., Tough and Troubled).

Boys' behavioral configurations were not related to the popularity classification of their group, $\chi^{2}(12, N=131)=10.96, p=$ .53 (see Table 7). However, there were two cell-specific relation-

Table 3

Sociometric Status by Boys' Behavioral Configurations

\begin{tabular}{|c|c|c|c|c|c|c|}
\hline \multirow[b]{2}{*}{ Configuration } & \multicolumn{5}{|c|}{ Sociometric status } & \multirow[b]{2}{*}{ Total } \\
\hline & Popular & Controversial & Average & Neglected & Rejected & \\
\hline \multicolumn{7}{|l|}{ Model } \\
\hline$n$ & 6 & 3 & 16 & 15 & $3 *$ & 43 \\
\hline$\%$ & 14.0 & 7.0 & 37.2 & 34.9 & 7.0 & \\
\hline \multicolumn{7}{|l|}{ Tough } \\
\hline$n$ & 3 & 2 & 4 & $2 *$ & $7 * *$ & 18 \\
\hline$\%$ & 16.7 & 11.1 & 22.2 & 11.1 & 38.9 & \\
\hline \multicolumn{7}{|l|}{ Unpopular } \\
\hline$n$ & 3 & 1 & 12 & 11 & 6 & 33 \\
\hline$\%$ & 9.1 & 3.0 & 36.4 & 33.3 & 18.2 & \\
\hline \multicolumn{7}{|l|}{ Troubled } \\
\hline$n$ & 2 & 3 & 17 & 18 & 6 & 46 \\
\hline$\%$ & 4.3 & 6.5 & 37.0 & 39.1 & 13.0 & \\
\hline \multicolumn{7}{|l|}{ Total } \\
\hline$n$ & 14 & 9 & 49 & 46 & 22 & 140 \\
\hline$\%$ & 10.0 & 6.4 & 35.0 & 32.9 & 15.7 & \\
\hline
\end{tabular}

$* p<.05 . \quad * * p<.01$. 
Table 4

Sociometric Status by Girls' Behavioral Configurations

\begin{tabular}{|c|c|c|c|c|c|c|}
\hline \multirow[b]{2}{*}{ Configuration } & \multicolumn{5}{|c|}{ Sociometric status } & \multirow[b]{2}{*}{ Total } \\
\hline & Popular & Controversial & Average & Neglected & Rejected & \\
\hline \multicolumn{7}{|l|}{ Model } \\
\hline$n$ & 15 & 5 & 14 & 9 & 3 & 46 \\
\hline$\%$ & 32.6 & 10.9 & 30.4 & 19.6 & 6.5 & \\
\hline \multicolumn{7}{|l|}{ Popular } \\
\hline$n$ & 13 & $11^{* *}$ & 13 & $5^{*}$ & 6 & 48 \\
\hline$\%$ & 27.1 & 22.9 & 27.1 & 10.4 & 12.5 & \\
\hline \multicolumn{7}{|l|}{ Below Average } \\
\hline$n$ & 13 & 3 & 21 & 17 & 3 & 57 \\
\hline$\%$ & 22.8 & 5.3 & 36.8 & 29.8 & 5.3 & \\
\hline \multicolumn{7}{|l|}{ Troubled } \\
\hline$n$ & 13 & 6 & 28 & 18 & 8 & 73 \\
\hline$\%$ & 17.8 & 8.2 & 38.4 & 24.7 & 11.0 & \\
\hline \multicolumn{7}{|l|}{ Total } \\
\hline$n$ & 54 & 25 & 76 & 49 & 20 & 224 \\
\hline$\%$ & 24.1 & 11.2 & 33.9 & 21.9 & 8.9 & \\
\hline
\end{tabular}

$* p<.05 . \quad * * p<.01$.

ships. Tough boys were less likely to be in nonpopular groups (Fisher's exact probability $<.05$ ) and more likely to be in popular groups (Fisher's exact probability $<.05$ ).

Because we were interested in differences between Tough and Troubled boys, we collapsed the peer-group type classifications into two categories: "associates with few popular peers" and "associates with many popular peers." The "associates with few popular peers" category combined the socially isolated, zeropopular, and nonpopular classifications. The "associates with many popular peers" category combined the popular and mixed classifications. Whereas $65.1 \%$ (28/43) of the Troubled boys were in the "associates with few popular peers" category, $70.6 \%(12 / 17)$ of the Tough boys were in the "associates with many popular peers" category. This difference was statistically significant, $\chi^{2}(1$, $N=131)=6.28, p<.05$.

Girls' behavioral configurations were related to the popularity classification of their peer group, $\chi^{2}(12, N=221)=37.32, p<$
.01 (see Table 8). Four cells in the matrix drove these effects. Popular girls were less likely to belong to zero-popular groups (Fisher's exact probability $<.01$ ) and more likely to belong to popular groups (Fisher's exact probability $<.01$ ) than expected by chance. Troubled girls tended to belong to zero-popular groups more (Fisher's exact probability $<.05$ ) and popular groups less (Fisher's exact probability $<.01$ ) than expected by chance.

\section{Behavioral Configurations and Teacher Ratings of Social Adaptation}

This section explores differences in teachers' assessments of youths' social adaptation in relation to their behavioral configurations. We expected that youths in the Troubled and Tough categories would have more behavioral difficulties (i.e., attention problems, hyperactivity, proactive and reactive aggression, andamong the Troubled youths_- being bullied), whereas Model youths

Table 5

Peer Nomination Factors by Boys' Behavioral Configurations

\begin{tabular}{|c|c|c|c|c|}
\hline \multirow[b]{2}{*}{ Cluster } & \multicolumn{4}{|c|}{ Peer-nomination factor } \\
\hline & Aggression & Prosocial Skills & Social Prominence & Internalizing \\
\hline \multicolumn{5}{|c|}{ Model $(n=43)$} \\
\hline$M$ & 3.18 & 8.22 & 9.94 & 4.27 \\
\hline$S D$ & 6.41 & 11.50 & 20.54 & 5.50 \\
\hline \multicolumn{5}{|c|}{ Tough $(n=18)$} \\
\hline$M$ & $21.38^{\mathrm{a}, \mathrm{c}}$ & 4.72 & 10.50 & 6.97 \\
\hline$S D$ & 31.84 & 3.42 & 12.75 & 5.08 \\
\hline \multicolumn{5}{|c|}{ Average $(n=33)$} \\
\hline$M$ & 7.29 & 4.25 & 8.10 & 4.80 \\
\hline$S D$ & 20.86 & 6.88 & 26.11 & 5.79 \\
\hline \multicolumn{5}{|c|}{ Troubled $(n=46)$} \\
\hline$M$ & 8.48 & $3.27^{\mathrm{a}}$ & $4.01^{\mathrm{a}, \mathrm{b}}$ & 4.78 \\
\hline$S D$ & 19.12 & 3.33 & 4.85 & 10.89 \\
\hline
\end{tabular}

${ }^{a}$ Significantly different from Model. ${ }^{\mathrm{b}}$ Significantly different from Tough. ${ }^{\mathrm{c}}$ Significantly different from Average. 
Table 6

Peer Nomination Factors by Girls’ Behavioral Configurations

\begin{tabular}{|c|c|c|c|c|}
\hline \multirow[b]{2}{*}{ Cluster } & \multicolumn{4}{|c|}{ Peer-nomination factor } \\
\hline & Aggression & Prosocial Skills & Social Prominence & Internalizing \\
\hline \multicolumn{5}{|l|}{ Model $(n=46)$} \\
\hline$M$ & 1.77 & 13.52 & 6.18 & 3.13 \\
\hline$S D$ & 2.69 & 14.72 & 6.27 & 4.47 \\
\hline \multicolumn{5}{|l|}{ Popular $(n=48)$} \\
\hline$M$ & $5.03^{\mathrm{a}, \mathrm{c}}$ & 14.15 & 9.69 & 5.09 \\
\hline$S D$ & 5.73 & 14.33 & 12.09 & 9.81 \\
\hline \multicolumn{5}{|c|}{ Below Average $(n=57)$} \\
\hline$M$ & 2.40 & $6.16^{\mathrm{a}, \mathrm{b}}$ & $3.57^{\mathrm{b}}$ & 6.17 \\
\hline$S D$ & 3.43 & 8.02 & 8.84 & 13.21 \\
\hline \multicolumn{5}{|l|}{ Troubled $(n=73)$} \\
\hline$M$ & $4.35^{\mathrm{a}}$ & $4.57^{\mathrm{a}, \mathrm{b}}$ & $3.43^{\mathrm{b}}$ & 2.66 \\
\hline$S D$ & 6.98 & 4.07 & 4.63 & 3.65 \\
\hline
\end{tabular}

${ }^{a}$ Significantly different from Model. ${ }^{\mathrm{b}}$ Significantly different from Popular. ${ }^{\mathrm{c}}$ Significantly different from Below Average.

would have higher ratings on involvement in extracurricular activities.

As shown in Table 9, the boys' configurations differed on all teacher measures of social adaptation: attention problems, $F(3$, $135)=6.97, p<.01$; class leadership, $F(3,135)=7.69, p<.01$; being bullied by peers, $F(3,135)=4.01, p<.01$; hyperactivity, $F(3,135)=8.46, p<.01$; bullying peers, $F(3,135)=24.64, p<$ .01 ; manipulating friendships, $F(3,135)=6.03, p<.01$; and involvement in extracurricular activities, $F(3,135)=10.00, p<$ .01. Post hoc Tukey's tests revealed that Model boys were rated as having fewer attention problems than Tough or Troubled boys, and Average boys had fewer attention problems than Troubled boys. Model and Tough boys were both rated as significantly higher in class leadership than Troubled boys, and Troubled boys were rated as being bullied by peers more often than were Model boys. Tough boys were rated as being more hyperactive than Average or Model boys, and Troubled boys were rated as more hyperactive than
Model boys. Troubled boys were also rated as bullying peers more often than was any other group, and Tough boys were rated as bullying peers more often than were Model boys. Troubled boys were also rated as manipulating friendships more often than were either Model or Average boys. In terms of involvement in extracurricular activities, Model and Tough boys were rated as more involved than were Average and Troubled boys.

The girls' configurations also differed on teacher ratings of attention problems, $F(3,220)=46.39, p<.01$; being bullied by peers, $F(3,220)=51.67, p<.01$; hyperactivity, $F(3,220)=$ $44.88, p<.01$; and involvement in extracurricular activities, $F(3$, $220)=23.36, p<.01$ (see Table 10). Post hoc Tukey's tests indicated that Troubled girls were rated as having more problems paying attention than were all the other configurations, and Model girls were rated as having fewer attention problems than were all the other configurations. Troubled girls were rated as more hyperactive than were all the other configurations, whereas Popular girls

Table 7

Popularity Group Type by Boys' Behavioral Configurations

\begin{tabular}{|c|c|c|c|c|c|c|}
\hline \multirow[b]{2}{*}{ Configuration } & \multicolumn{4}{|c|}{ Popularity group type } & \multirow[b]{2}{*}{ Isolates } & \multirow[b]{2}{*}{ Total } \\
\hline & Zero popular & Nonpopular & Popular & Mixed & & \\
\hline \multicolumn{7}{|l|}{ Model } \\
\hline$n$ & 11 & 9 & 7 & 9 & 5 & 41 \\
\hline$\%$ & 26.8 & 22.0 & 17.1 & 22.0 & 12.2 & \\
\hline \multicolumn{7}{|l|}{ Tough } \\
\hline$n$ & 4 & $0 *$ & $7 *$ & 5 & 1 & 17 \\
\hline$\%$ & 23.5 & 0.0 & 41.2 & 29.4 & 5.9 & \\
\hline \multicolumn{7}{|l|}{ Average } \\
\hline$n$ & 5 & 7 & 7 & 6 & 5 & 30 \\
\hline$\%$ & 16.7 & 23.3 & 23.3 & 20.0 & 16.7 & \\
\hline \multicolumn{7}{|l|}{ Troubled } \\
\hline$n$ & 10 & 12 & 8 & 7 & 6 & 43 \\
\hline$\%$ & 23.3 & 27.9 & 18.6 & 16.3 & 14.0 & \\
\hline \multicolumn{7}{|l|}{ Total } \\
\hline$n$ & 30 & 28 & 29 & 27 & 17 & 131 \\
\hline$\%$ & 22.9 & 28.0 & 22.1 & 20.6 & 13.0 & \\
\hline
\end{tabular}

$* p<.05$. 
Table 8

Popularity Group Type by Girls' Behavioral Configurations

\begin{tabular}{|c|c|c|c|c|c|c|}
\hline \multirow[b]{2}{*}{ Configuration } & \multicolumn{4}{|c|}{ Popularity group type } & \multirow[b]{2}{*}{ Isolates } & \multirow[b]{2}{*}{ Total } \\
\hline & Zero popular & Nonpopular & Popular & Mixed & & \\
\hline \multicolumn{7}{|l|}{ Model } \\
\hline$n$ & 14 & 12 & 5 & 12 & 1 & 44 \\
\hline$\%$ & 31.8 & 27.3 & 11.4 & 27.3 & 2.3 & \\
\hline \multicolumn{7}{|l|}{ Popular } \\
\hline$n$ & $7 * *$ & 11 & $19 * *$ & 10 & 1 & 48 \\
\hline$\%$ & 14.6 & 22.9 & 39.6 & 20.8 & 2.1 & \\
\hline \multicolumn{7}{|l|}{ Below Average } \\
\hline$n$ & 15 & 20 & 8 & 8 & 5 & 56 \\
\hline$\%$ & 26.8 & 35.7 & 14.3 & 14.3 & 8.9 & \\
\hline \multicolumn{7}{|l|}{ Troubled } \\
\hline$n$ & $28^{*}$ & 20 & $3 * *$ & 16 & 6 & 73 \\
\hline$\%$ & 38.4 & 27.4 & 4.1 & 21.9 & 8.2 & \\
\hline \multicolumn{7}{|l|}{ Total } \\
\hline$n$ & 64 & 63 & 35 & 46 & 13 & 221 \\
\hline$\%$ & 29.0 & 28.5 & 15.8 & 20.8 & 5.9 & \\
\hline
\end{tabular}

$* p<.05 . \quad * * p<.01$.

were rated as more hyperactive than were Model and Below Average girls. Troubled girls were rated as being bullied by peers more than were all other configurations of girls. Finally, Model and Popular girls were rated as more involved in extracurricular activities than were Below Average and Troubled girls.

\section{Discussion}

This study provides a new perspective on the social relations of aggressive youths. Although some aggressive youths may be so- cially marginalized, others appear to have strong social skills and are among the leaders of popular or prominent peer groups. Building on previous work in early (e.g., Estell et al., 2002) and late (Farmer \& Rodkin, 1996; Rodkin et al., 2000) elementary classrooms, we identified two distinct types of aggressive boys in middle school. Consistent with results from research undertaken in elementary school were our findings that teachers viewed Tough boys as aggressive, popular, and strong in social skills (i.e., the Affiliative factor). Conversely, Troubled boys were perceived to

Table 9

Teacher Ratings of Social Adaptation by Boys' Behavioral Configurations

\begin{tabular}{|c|c|c|c|c|}
\hline \multirow[b]{2}{*}{ Rating } & \multicolumn{4}{|c|}{ Configuration } \\
\hline & $\begin{array}{c}\text { Model } \\
(n=43)\end{array}$ & $\begin{array}{c}\text { Tough } \\
(n=18)\end{array}$ & $\begin{array}{l}\text { Average } \\
(n=33)\end{array}$ & $\begin{array}{l}\text { Troubled } \\
(n=46)\end{array}$ \\
\hline \multicolumn{5}{|l|}{ Attention problems } \\
\hline$M$ & 2.88 & $4.67^{\mathrm{a}}$ & 3.31 & $4.48^{\mathrm{a}, \mathrm{c}}$ \\
\hline$S D$ & 2.04 & 1.37 & 2.02 & 1.94 \\
\hline \multicolumn{5}{|l|}{ Class leader } \\
\hline$M$ & 4.40 & 4.00 & 3.41 & $2.72^{\mathrm{a}, \mathrm{b}}$ \\
\hline$S D$ & 1.89 & 1.37 & 1.90 & 1.46 \\
\hline \multicolumn{5}{|l|}{ Bullied by peers } \\
\hline$M$ & 1.84 & 2.61 & 2.25 & $2.85^{\mathrm{a}}$ \\
\hline$S D$ & 1.17 & 1.24 & 1.55 & 1.59 \\
\hline \multicolumn{5}{|l|}{ Hyperactive } \\
\hline$M$ & 2.28 & $4.50^{\mathrm{a}, \mathrm{c}}$ & 2.53 & $3.54^{\mathrm{a}}$ \\
\hline$S D$ & 1.65 & 2.07 & 1.65 & 1.95 \\
\hline \multicolumn{5}{|l|}{ Bullies peers } \\
\hline$M$ & 1.64 & $3.11^{\mathrm{a}}$ & 2.22 & $4.30^{\mathrm{a}, \mathrm{b}, \mathrm{c}}$ \\
\hline$S D$ & 1.28 & 1.57 & 1.34 & 1.81 \\
\hline \multicolumn{5}{|l|}{ Manipulates friends } \\
\hline$M$ & 2.16 & 3.11 & 2.50 & $3.50^{\mathrm{a}, \mathrm{c}}$ \\
\hline$S D$ & 1.77 & 1.36 & 1.39 & 1.56 \\
\hline \multicolumn{5}{|c|}{ Involved in extracurricular activities } \\
\hline$M$ & 4.84 & 5.17 & $3.44^{\mathrm{a}, \mathrm{b}}$ & $3.24^{\mathrm{a}, \mathrm{b}}$ \\
\hline$S D$ & 1.88 & 1.58 & 1.74 & 1.68 \\
\hline
\end{tabular}

${ }^{a}$ Significantly different from Model. ${ }^{\mathrm{b}}$ Significantly different from Tough. ${ }^{\mathrm{c}}$ Significantly different from Average. 
Table 10

Teacher Ratings of Social Adaptation by Girls' Behavioral Configurations

\begin{tabular}{|c|c|c|c|c|}
\hline \multirow[b]{2}{*}{ Rating } & \multicolumn{4}{|c|}{ Configuration } \\
\hline & $\begin{array}{c}\text { Model } \\
(n=46)\end{array}$ & $\begin{array}{l}\text { Popular } \\
(n=48)\end{array}$ & $\begin{array}{l}\text { Below Average } \\
\quad(n=57)\end{array}$ & $\begin{array}{l}\text { Troubled } \\
(n=73)\end{array}$ \\
\hline \multicolumn{5}{|l|}{ Attention problems } \\
\hline$M$ & 1.09 & $2.77^{\mathrm{a}}$ & $2.82^{\mathrm{a}}$ & $4.40^{\mathrm{a}, \mathrm{b}, \mathrm{c}}$ \\
\hline$S D$ & 0.46 & 1.61 & 1.79 & 1.61 \\
\hline \multicolumn{5}{|l|}{ Bullied by peers } \\
\hline$M$ & 1.15 & 1.60 & 1.60 & $3.35^{\mathrm{a}, \mathrm{b}, \mathrm{c}}$ \\
\hline$S D$ & 0.63 & 0.71 & 1.10 & 1.43 \\
\hline \multicolumn{5}{|l|}{ Hyperactive } \\
\hline$M$ & 1.33 & $2.94^{\mathrm{a}, \mathrm{c}}$ & 1.49 & $3.90^{\mathrm{a}, \mathrm{b}, \mathrm{c}}$ \\
\hline$S D$ & 0.87 & 1.93 & 1.17 & 1.50 \\
\hline \multicolumn{5}{|c|}{ Involved in extracurricular activities } \\
\hline$M$ & 5.61 & 5.10 & $3.84^{\mathrm{a}, \mathrm{b}}$ & $3.38^{\mathrm{a}, \mathrm{b}}$ \\
\hline$S D$ & 1.76 & 1.36 & 2.01 & 1.31 \\
\hline
\end{tabular}

be aggressive, unpopular, and low in social skills. By including a focus on social aggression, the current study also identified two distinct types of aggressive girls. Popular girls were perceived by teachers as popular, manipulative, moderately high in social skills, and being leaders, whereas Troubled girls were viewed as aggressive, unpopular, manipulative, and low in social skills.

The importance of the distinctions between the subtypes of aggressive youths comes to the forefront when they are considered in light of other measures of social relations. Tough boys were significantly higher on peer nominations of social prominence (i.e., leader, athletic, cool, and popular) than were Troubled boys, they were more likely to associate with popular peers, and they were viewed by teachers as leaders who were frequently involved in extracurricular activities. Nonetheless, compared with all other boys, Tough boys were more likely to have rejected sociometric status and less likely to be neglected. Likewise, girls in the Popular configuration were viewed by peers as aggressive, socially skilled, and socially prominent, they were perceived by teachers as involved in extracurricular activities, and they tended to associate with popular peers. However, similar to Tough boys, Popular girls were significantly more likely to be controversial and less likely to be neglected, whereas Troubled girls did not significantly differ from other girls on sociometric status.

An intriguing finding of the present study is that although they were more likely to be disliked by peers (i.e., rejected or controversial status), Tough boys and Popular girls were perceived by peers and teachers as popular leaders and athletes who were more likely to be involved in extracurricular activities. Although this is not in agreement with current conceptions of rejected sociometric status, it is highly consistent with results from investigations of perceived popularity and ethnographic studies of social stratification. Many youth who are viewed as popular by peers have a mix of positive and negative characteristics and often are not well liked (LaFontana \& Cillessen, 2002; Lease et al., 2002; Luthar \& McMahon, 1996). In fact, Parkhurst and Hopmeyer (1998) found that $11 \%$ of rejected-status middle-school students were high in peerperceived popularity, and $62 \%$ were average. Youth who are perceived as popular often wield considerable power in the social structure and use socially aggressive strategies to maintain their dominance over others (Adler et al., 1992; Evans \& Eder, 1993; Lease et al., 2002). Social hierarchies tend to emerge in which athletic and physically dominant boys make up the most popular boys' groups (Adler \& Adler, 1996; Eder \& Parker, 1987). Although leaders of these groups are perceived by peers as being the most popular, their high status paired with their bullying and socially aggressive tactics can result in their being disliked by others (Adler \& Adler, 1995; Adler et al., 1992; Evans \& Eder, 1993).

This point raises a question of methodology. Unlike teacher ratings and peer assessments, sociometric status is not a direct measure of popularity. Rather, popularity is inferred from how well an individual is liked by others. Although this index of likability predicts later adjustment (Kupersmidt, Coie, \& Dodge, 1990; Parker \& Asher, 1987), current conceptions of the social positions and peer relations of aggressive youths may be somewhat obscured by this measure in two related ways. First, rather than having little influence in the social structure, it appears that some boys with rejected status may be highly influential. Second, rather than being relegated to deviant peer groups and associating only with unpopular aggressive peers, it appears that Tough boys and Popular girls are integrated in the mainstream social structure, are highly involved in extracurricular activities, and tend not to affiliate with aggressive youths who are perceived by peers and teachers as less popular. When considered in light of the peer-perceived popularity and ethnographic literature, the fact that some aggressive youths are popular athletes and leaders who are highly influential but not well liked seems reasonable.

It is possible that the present results are unique to this lowincome, rural, predominantly African American sample. Coie and Jacobs (1993) suggested that the popularity of aggressive youth may reflect general behavioral norms in communities where poverty, social stress, racial prejudice, and crime rates are high Consistent with this view are findings that aggressive youth are more likely to be popular in classrooms where aggression is socially valued or accepted (Henry et al., 2000; Stormshak, Bierman, Bruschi, Dodge, \& Coie, 1999). Likewise, associating with deviant peers has been linked to higher social preference scores 
and status in a high-poverty inner-city sample of early adolescents (Coie \& Jacobs, 1993).

However, the present study is consistent with work on the social relations of inner-city minority youth (Luthar \& McMahon, 1996) in suggesting that both prosocial and antisocial behavioral profiles are associated with popularity and high social positions. Many of the African American early adolescents in this high-risk rural community had behavioral profiles that were characterized by high levels of prosocial characteristics and low levels of antisocial ones. These Model youths tended to be viewed favorably by peers and were likely to be members of popular peer groups. They were also viewed by teachers as being class leaders and as being involved in extracurricular activities.

Further, the present findings for Tough boys and Popular girls in this early-adolescent African American sample are consistent with work on school social dynamics and bullying in European American samples. Ethnographic studies with predominantly White samples indicate that many youths who are perceived by peers as popular tend to be not well liked, are socially manipulative, are physically dominant, and are primary instigators of conflict and aggression (Adler \& Adler, 1998; Eder, 1985; Evans \& Eder, 1993; Kinney, 1993; Merten, 1997). These characteristics appear to be the case regardless of whether the samples come from rural communities or middle- or upper-middle-class suburbs. What these studies depict is that some aggressive youths associate with popular peers and, depending on one's perspective, may be dominant leaders or popular bullies who have considerable influence in the classroom social structure (Farmer, 2000; Lease et al., 2002). Other aggressive youths appear to be unpopular bullies who associate with less popular peers and who are at increased risk of being victims (Pellegrini, Bartini, \& Brooks, 1999; Pepler, Craig, \& Roberts, 1998). Therefore, although it is likely that ethnic and community factors may contribute to social adjustment, the findings of the present study appear to reflect natural social dynamics that are not context or population specific.

The present findings do not support the confluence model (Dishion et al., 1994) or the deviant peer-group hypothesis (Bagwell et al., 2000) and may provide a new perspective on interventions that focus on school social dynamics. The present study confirms that rather than associating together, popular and unpopular aggressive subtypes of youths tend to associate with peers who are similar to them on perceived popularity. Therefore, these results suggest that rather than being leaders of deviant peer groups composed primarily of unpopular peers, popular aggressive youths may not associate with their unpopular counterparts. It is possible that these two types of aggressive youth may be enemies. Interventions that attempt to use popular aggressive youths as agents of influence with unpopular aggressive peers may be counterproductive. The current findings suggest a need for social interventions that are sensitive to both inter- and intragroup relations and that can be flexible and responsive to the ever-changing social dynamics in classrooms and schools. This means that social interventions must be developed and embedded within the general instructional and classroom management strategies of teachers, administrators, and other school personnel (see Cartledge \& Milburn, 1996; Farmer, 2000; Troop \& Asher, 1999).

Although the findings here are consistent with other survey and ethnographic research, some of the methods differ from those used in other studies of social relations and may help to explain differences between current and previous results. Compared with re- search on social relations among middle-childhood youths in elementary schools, less work has focused on early adolescents in middle-school settings (Luthar \& McMahon, 1996). There are clear differences between the social contexts in elementary and middle schools that must be considered in the development of procedures and methods. Namely, in elementary school, the social context is typically a self-contained classroom. That is, 25-30 students spend their day together and have relatively little interaction with peers outside their class. In such a setting, it is appropriate to use the classroom as the unit of analysis and to focus on the classroom in the peer-generated measures.

In middle school, the social context becomes much broader. Students change classes and typically do not have all the same peers in each class. More important, there is considerably more unstructured time throughout the day (i.e., school arrival before class, class transitions, lunch, after-school waiting for transportation) that provides students with the opportunity to interact and establish affiliations with peers in other classrooms and grades. To accurately assess the social dynamics in such settings, it is necessary to view the entire school as the relevant social context and to use saturated sampling techniques. For this reason, the present study used the school rather than the classroom as the social unit boundary for the peer-generated data.

Because the school was used as the unit of analysis, it was not appropriate to generate standardized classroom scores for the peer data, as is typically done in other studies. Further, the total number of possible nominations is much larger (i.e., 150 or more vs. 20) when the school rather than the classroom is the unit of analysis. This results in much smaller peer assessment scores. Therefore, these scores should not be compared with those from studies in which the class is the unit of analysis. However, this constraint in no way compromises the validity of these scores. On the contrary, this method was a highly effective way to identify youths who were prominent in the social structure on specific characteristics. Identifying salient individuals with peer assessment techniques and supplementing this identification with teacher ratings of all participants on parallel constructs helped to ensure a comprehensive depiction of the school social dynamics.

A second limitation of this study is that there were relatively few youths in some of the categories of interest, particularly for boys (i.e., the Tough configuration, the popular sociometric status, and the controversial status). Although the proportions of boys in these various categories are generally consistent with those in other work, there is clearly a need to replicate these findings with a larger sample of boys.

A third limitation is that this study is not longitudinal, and therefore there is no information on the developmental trajectories of these youths. It has been posited that aggressive youths may become more popular as they grow older. Bukowski, Sippola, and Newcomb (2000) found that aggressive youths became more attractive to peers as they transitioned to middle school, whereas youths with good classroom behavior became less attractive. The present results do not support this view. Perceived popular aggressive youth appear to be less liked by their peers. This result is consistent with Eder's (1985) finding that perceived popular girls became increasingly less liked in middle school because they used socially aggressive strategies to protect their popularity. Because distinct subtypes of aggressive youths have been identified in the elementary school years (e.g., Estell et al., 2002; Rodkin et al., 
2000), we expect that the current findings do not represent a developmental progression.

In conclusion, this research extends the knowledge base on the social dynamics of aggression in schools. Some of the most aggressive youths also appeared to be among the most socially prominent and influential. More work that focuses on the social dynamics of aggression in schools is needed. Investigations similar to the present one need to be conducted at varying age levels (i.e., elementary, middle, and high schools) with samples of varying ethnic composition. In addition, longitudinal work is needed to examine the developmental patterns of the various subtypes.

\section{References}

Adler, P. A., \& Adler, P. (1995). Dynamics of inclusion and exclusion in preadolescent cliques. Social Psychology Quarterly, 58, 145-162.

Adler, P. A., \& Adler, P. (1996). Preadolescent clique stratification and the hierarchy of identity. Sociological Inquiry, 66, 111-142.

Adler, P. A., \& Adler, P. (1998). Peer power: Preadolescent culture and identity. New Brunswick, NJ: Rutgers University Press.

Adler, P. A., Kless, S., \& Adler, P. (1992). Socialization to gender roles: Popularity among elmentary school boys and girls. Sociology of Education, 65, 169-187.

Aldenderfer, M. S., \& Blashfield, R. K. (1984). Cluster analysis. Beverly Hills, CA: Sage.

Bagwell, C. L., Coie, J. D., Terry, R. A., \& Lochman, J. E. (2000). Peer clique participation and social status in preadolescence. Merrill-Palmer Quarterly, 46, 280-305.

Bukowski, W. M., Sippola, L. K., \& Newcomb, A. F. (2000). Variations in patterns of attraction of same- and other-sex peers during early adolescence. Developmental Psychology, 36, 147-154.

Cadwallader, T. W., Farmer, T. W., Cairns, B. D., Leung, M-C., Clemmer, J. T., Gut, D. M., \& Reese, L. E. (2002). The social relations of rural African American early adolescents and proximal impact of the School Engagement Project. Journal of School Psychology, 40, 213-237.

Cairns, R. B. (1983). Sociometry, psychometry, and social structure: A commentary on six recent studies of popular, rejected, and neglected children. Merrill-Palmer Quarterly, 29, 429-438.

Cairns, R. B., \& Cairns, B. D. (1994). Lifelines and risks: Pathways of youth in our time. New York: Harvester Wheatsheaf

Cairns, R. B., Cairns, B. D., Neckerman, H. J., Ferguson, L. L., \& Gariépy, J-L. (1989). Growth and aggression: I. Childhood to early adolescence. Developmental Psychology, 25, 320-330.

Cairns, R. B., Cairns, B. D., Neckerman, H. J., Gest, S., \& Gariépy, J-L. (1988). Social networks and aggressive behavior: Peer support or peer rejection? Developmental Psychology, 24, 815-823.

Cairns, R. B., Gariépy, J-L., Kindermann, T., \& Leung, M-C. (1996). Identifying social clusters in natural settings. Unpublished manuscript, University of North Carolina at Chapel Hill.

Cairns, R. B., Leung, M-C., Buchanan, L., \& Cairns, B. D. (1995). Friendships and social networks in childhood and adolescence: Fluidity, reliability, and interrelations. Child Development, 66, 1330-1345.

Cairns, R. B., Leung, M-C., Gest, S. D., \& Cairns, B. D. (1995). A brief method for assessing social development: Structure, reliability, stability, and developmental validity of the Interpersonal Competence Scale. Behaviour Research and Therapy, 33, 725-736.

Cairns, R. B., Perrin, J. E., \& Cairns, B. D. (1985). Social structure and social cognition in early adolescence: Affiliative patterns. Journal of Early Adolescence, 5, 339-355.

Cantrell, V. L., \& Prinz, R. J. (1985). Multiple perspectives of rejected, neglected, and accepted children: Relation between sociometric status and behavioral characteristics. Journal of Consulting and Clinical Psychology, 53, 884-889.

Cartledge, G., \& Milburn, J. F. (1996). Cultural diversity and social skills instruction: Understanding ethnic and gender differences. Champaign, IL: Research Press.

Coie, J. D., \& Dodge, K. A. (1998). Aggression and antisocial behavior. In N. Eisenberg (Ed.), Handbook of child psychology: Social, emotional, and personality development (5th ed., pp. 779-862). New York: Wiley.

Coie, J. D., Dodge, K. A., \& Coppotelli, H. (1982). Dimensions and types of social status: A cross-age perspective. Developmental Psychology, 18, 557-570.

Coie, J. D., \& Jacobs, M. R. (1993). The role of social context in the prevention of conduct disorder. Development and Psychopathology, 5, 263-275.

Coie, J. D., Terry, R., Zakriski, A., \& Lochman, J. (1995). Early adolescent social influences on delinquent behavior. In J. McCord (Ed.), Coercion and punishment in long-term perspectives (pp. 229-244). New York: Cambridge University Press.

Corsaro, W. A., \& Eder, D. (1990). Children's peer cultures. Annual Review of Sociology, 16, 197-220.

Dishion, T. J., Patterson, G. R., \& Griesler, P. C. (1994). Peer adaptations in the development of antisocial behavior: A confluence model. In L. R. Huesmann (Ed.), Aggressive behavior: Current perspectives (Plenum Series in Social/Clinical Psychology; pp. 61-95). New York: Plenum Press.

Eder, D. (1985). The cycle of popularity: Interpersonal relations among female adolescents. Sociology of Education, 58, 154-165.

Eder, D., \& Parker, S. (1987). The cultural production and reproduction of gender: The effect of extracurricular activities on peer-group culture. Sociology of Education, 60, 200-213.

Estell, D. B., Cairns, R. B., Farmer, T. W., \& Cairns, B. D. (2002). Aggression in inner-city early elementary classrooms: Individual and peer-group configurations. Merrill-Palmer Quarterly, 48, 52-76.

Evans, C., \& Eder, D. (1993). "No exit": Processes of social isolation in the middle school. Journal of Contemporary Ethnography, 22, 139-170.

Farmer, T. W. (2000). Social dynamics of aggressive and disruptive behavior in school: Implications for behavior consultation. Journal of Educational and Psychological Consultation, 11, 299-322.

Farmer, T. W., \& Cairns, R. B. (1991). Social networks and social status in emotionally disturbed children. Behavioral Disorders, 16, 288-298.

Farmer, T. W., \& Hollowell, J. L. (1994). Social networks in mainstream classrooms: Social affiliations and behavioral characteristics of students with emotional and behavioral disorders. Journal of Emotional and Behavioral Disorders, 2, 143-155; 163.

Farmer, T. W., Leung, M-C., Pearl, R., Rodkin, P. C., Cadwallader, T. W., \& Van Acker, R. (2002). Deviant or diverse groups? The peer affiliations of aggressive elementary students. Journal of Educational Psychology, 94, 611-620.

Farmer, T. W., \& Rodkin, P. C. (1996). Antisocial and prosocial correlates of classroom social positions: The social network centrality perspective. Social Development, 5, 176-190.

Farmer, T. W., Rodkin, P. C., Pearl, R., \& Van Acker, R. (1999). Teacherassessed behavioral configurations, peer-assessments, and self-concepts of elementary students with mild disabilities. Journal of Special Education, 33, 66-80.

Farmer, T. W., Stuart, C. B., Lorch, N. H., \& Field, E. (1993). The social behavior and peer relations of emotionally and behaviorally disturbed students in residential treatment: A pilot study. Journal of Emotional and Behavioral Disorders, 1, 223-234.

Farver, J. A. M. (1996). Aggressive behavior in preschooler's social networks: Do birds of a feather flock together? Early Childhood Re search Quarterly, 11, 333-350.

Galen, B. R., \& Underwood, M. K. (1997). A developmental investigation of social aggression among children. Developmental Psychology, 33 $589-600$

Gest, S. D., Farmer, T., Cairns, B. D., \& Xie, H. (in press). Identifying children's peer social networks in school classrooms: Links between peer reports and observed interactions. Social Development. 
Hawley, P. H., Little, T. D., \& Pasupathi, M. (2002). Winning friends and influencing peers: Strategies of peer influence in late childhood. International Journal of Behavioral Development, 26, 466-474.

Henry, D., Guerra, N., Huesmann, R., Tolan, P., Van Acker, R., \& Eron, L. (2000). Normative influences on aggression in urban elementary school classrooms. American Journal of Community Psychology, 28, $59-81$.

Kindermann, T. A. (1993). Natural peer groups as contexts for individual development: The case of children's motivation in school. Developmental Psychology, 29, 970-977.

Kinney, D. A. (1993). From "nerds to normals": The recovery of identity among adolescents from middle school to high school. Sociology of Education, 66, 21-40.

Kupersmidt, J. B., Coie, J. D., \& Dodge, K. A. (1990). The role of poor peer relationships in the development of disorder. In S. R. Asher \& J. D. Coie (Eds.), Peer rejection in childhood (pp. 274-305). New York: Cambridge University Press.

LaFontana, K. M., \& Cillessen, A. H. N. (1998). The nature of children's stereotypes of popularity. Social Development, 7, 301-320.

LaFontana, K. M., \& Cillessen, A. H. N. (1999). Children's interpersonal perceptions as a function of sociometric and peer-perceived popularity. Journal of Genetic Psychology, 160, 225-242.

LaFontana, K. M., \& Cillessen, A. H. (2002). Children's perceptions of popular and unpopular peers: A multimethod assessment. Developmental Psychology, 38, 635-647.

Lease, A. M., Kennedy, C. A., \& Axlerod, J. L. (2002). Children's social constructions of popularity. Social Development, 11, 87-109.

Leung, M. (1996). Social networks and self-enhancement in Chinese children: A comparison of self reports and peer reports of group membership. Social Development, 6, 146-157.

Luthar, S., \& McMahon, T. J. (1996). Peer reputation among inner-city adolescents: Structure and correlates. Journal of Research on Adolescence, 6, 581-603.

Mahoney, J. L. (2000). School extracurricular activity participation as a moderator in the development of antisocial patterns. Child Development, $71,502-516$.

Masten, A. S., Morison, P., \& Pellegrini, D. S. (1985). A revised class play method of peer assessment. Developmental Psychology, 21, 523-533.

Merten, D. E. (1997). The meaning of meanness: Popularity, competition, and conflict among junior high school girls. Sociology of Education, 70, 175-191.

Parker, J. G., \& Asher, S. R. (1987). Peer relations and later personal adjustment: Are low-accepted children at risk? Psychological Bulletin, 102, 357-389.

Parkhurst, J. T., \& Hopmeyer, A. (1998). Sociometric popularity and peer-perceived popularity: Two distinct dimensions of peer status. Journal of Early Adolescence, 18, 125-144.

Pearl, R., Farmer, T. W., Van Acker, R., Rodkin, P. C., Bost, K. K., Coe, M., \& Henley, W. (1998). The social integration of students with mild disabilities in general education classrooms: Peer group membership and peer-assessed social behavior. Elementary School Journal, 99, 167-185.

Pellegrini, A. D., Bartini, M., \& Brooks, F. (1999). School bullies, victims, and aggressive victims: Factors relating to group affiliation and victimization in early adolescence. Journal of Educational Psychology, 91, 216-224.

Pepler, D. J., Craig, W. M., \& Roberts, W. L. (1998). Observations of aggressive and nonaggressive children on the school playground. Merrill-Palmer Quarterly, 44, 55-76.

Poulin, F., Dishion, T. J., \& Haas, E. (1999). The peer influence paradox: Friendship quality and deviancy training within male adolescent friendships. Merrill-Palmer Quarterly, 45, 42-61.

Rodkin, P., Farmer, T. W., Pearl, R., \& Van Acker, R. (2000). The heterogeneity of popularity in boys: Antisocial and prosocial configurations. Developmental Psychology, 36, 14-24.

Rubin, K. H., Bukowski, W., \& Parker, J. (1998). Peer interactions, relationships, and groups. In N. Eisenberg (Ed.), Handbook of child psychology: Social, emotional, and personality development (5th ed., pp. 619-700). New York: Wiley.

Snyder, J., Horsch, E., \& Childs, J. (1997). Peer relationships of young children: Affiliative choices and the shaping of aggressive behavior. Journal of Clinical Child Psychology, 26, 145-156.

Stormshak, E. A., Bierman, K. L., Bruschi, C., Dodge, K. A., \& Coie, J. D. (1999). The relation between behavior problems and peer preference in different classroom contexts. Child Development, 70, 169-182.

Troop, W. P., \& Asher, S. R. (1999). Teaching peer relationship competence in schools. In R. J. Stevens (Ed.), Teaching in American schools (pp. 141-171). Columbus, OH: Merrill.

Underwood, M. K. (2002). Sticks and stones and social exclusion: Aggression among girls and boys. In P. K. Smith \& C. H. Hart (Eds.), Blackwell handbook of childhood social development (Blackwell Handbooks of Developmental Psychology, pp. 533-548). Malden, MA: Blackwell.

Ward, J. (1963). Hierarchical grouping to optimize an objective function. Journal of the American Statistical Association, 58, 236-244.

Xie, H., Cairns, R. B., \& Cairns, B. D. (1999). Social network centrality and social competence among inner-city children. Journal of Emotional and Behavioral Disorders, 7, 147-155.

Xie, H., Cairns, R. B., \& Cairns, B. D. (2002). The development of social aggression and physical aggression: A narrative analysis of interpersonal conflicts. Aggressive Behavior, 28, 341-355.

Xie, H., Swift, D. J., Cairns, B. D., \& Cairns, R. B. (2002). Aggressive behaviors in social interaction and developmental adaptation: A narrative analysis of interpersonal conflicts during early adolescence. Social Development, 11, 205-224.

Received April 12, 2002

Revision received May 27, 2003

Accepted June 4, 2003

\section{E-Mail Notification of Your Latest Issue Online!}

Would you like to know when the next issue of your favorite APA journal will be available online? This service is now available to you. Sign up at http://watson.apa.org/ notify/and you will be notified by e-mail when issues of interest to you become available! 